
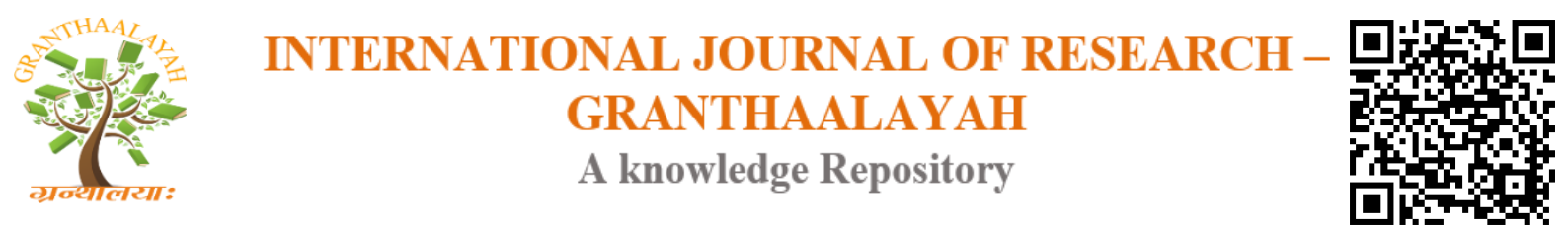

Science

\title{
PREPARATION AND SENSORY EVALUATION OF COOKIES SUPPLEMENTED WITH SPINACH (AMARANTHUS GANGETICS)
}

\author{
Dhanabaaghyam. $R^{* 1}$, Keerthini Raga. G. $S^{2}$, Sanjana. $S^{3}$, Suganya. G ${ }^{4}$ \\ ${ }^{* 1,2,3,4}$ Food Processing and Preservation Technology, Avinashilingam Institute for Home \\ Science and Higher Education for Women, School of Engineering, Coimbatore, India
}

\begin{abstract}
Spinach [Amaranthus gangetics] leaves were dried in a tray drier at $55^{\circ} \mathrm{C}$ and ground to pass through $220 \mu \mathrm{m}$ mesh to obtain spinach powder. Micronutrient is rich in Amaranthus gangetics. The spinach has rich source of vitamin C, folate and minerals. The physico-chemical analysis and sensory evaluation was done to know the acceptability of cookies incorporated with red spinach powder. These were evaluated for sensory analysis that included color, flavor, taste, and overall acceptability. The spinach cookies were analyzed for analytical and chemical analysis, which includes moisture content and total ash.
\end{abstract}

Keywords: Spinach Powder; Micronutrient; Physico-Chemical; Sensory Evaluation.

Cite This Article: Dhanabaaghyam. R, Keerthini Raga. G. S, Sanjana. S, and Suganya. G. (2018). "PREPARATION AND SENSORY EVALUATION OF COOKIES SUPPLEMENTED WITH SPINACH (AMARANTHUS GANGETICS)." International Journal of Research Granthaalayah, 6(9), 41-48. https://doi.org/10.5281/zenodo.1435216.

\section{Introduction}

Red thandu keerai or Amaranthus gangeticus belongs to the family Amaranthaceae. They are widely spread in all tropical and subtropical regions of the world. This is the annual flowering plant species which is suitable for any habitat and it grows above $3 \mathrm{ft}$ to below $8 \mathrm{ft}$ height [1]. Red spinach is native to South America and was introduced to Asia, Europe and Africa. Red spinach grows vigorously in warm climate round the year in well aerated sandy soil. Red spinach is a fastgrowing vegetable during summer season and reaches up to two feet height within 30 to 40 days. Red spinach is one of the dishes that contribute taste and much nutrition that results in strong body. Likewise, Amaranthus caudatus are used in mid July to make a special dish called as thandu keerai kolumbu for Hindu goddess. The thick, tasty and juicy stems add more flavors to the dish and it is more suitable for cooking this delicious spinach variety [1].

The women were so stronger in olden days, because they ate one of the spinach variety to boost their blood circulation, immunity level, active body parts to live a effortless life. The spinach is 
the richest source of vitamin $\mathrm{A}, \mathrm{B} 6, \mathrm{~K}$ and $\mathrm{C}$, also good source of folate and minerals. It is helps in digestion as it contains a lot of fiber.

In North America, including the United Kingdom, the most common word for a crisp cookie is biscuit. The term cookie is normally used to describe chewier ones. Cookies that are baked as a solid layer on a sheet pan and then cut, rather than being baked as individual pieces, are called bar cookies [2]. Cookies are most commonly baked until crisp or just long enough that they remain soft, but some kinds of cookies are not baked at all. Cookies are made in a wide variety of styles, using an array of ingredients including flour, sugar and some type of oil or fat [6].

Cookies came to America through the Dutch in New Amsterdam in the late 1620s. The Dutch word "koekje" was Anglicized to "cookie". The earliest reference to cookies in America is in 1703[5]. The objective was to develop cookies with good taste, texture and appearance, which resembles as closely as possible to the wheat flour based product. The textural property and sensory quality of cookies are taken into consideration to improve the quality of cookies.

An approach in the present study was to produce cookies with high nutrient content, which is obtained from the spinach. The objective was to develop cookies with good taste, texture and appearance. The sensory quality of cookies is taken into consideration to improve the quality of cookies.

\section{Materials and Methods}

\section{Procurement of Raw Material}

Good quality of red spinach and other major and minor ingredients such as refined wheat flour, butter, sugar, leavens and salt were purchased from the local market of Coimbatore.

\section{Experimental Plan}

The experimental plan used for the present research is given in table 1. Fig 1 shows the flow chart for the preparation of red spinach powder and fig 2 shows the preparation of cookies. Table 2 shows the different combination of refined wheat flour, butter and icing sugar for the preparation of cookies [in $\mathrm{g}$ ].

Table 1: Experimental plan

\begin{tabular}{|l|l|l|l|}
\hline S.No. & Parameter & Level & Description \\
\hline 1. & Product & 1 & Cookie \\
\hline 2. & Ingredients & 5 & $\begin{array}{l}\text { Refined wheat flour, butter, icing sugar, baking soda, red } \\
\text { spinach powder }\end{array}$ \\
\hline 3. & Samples & 17 & Physio chemical analysis, sensory evaluation \\
\hline 4. & Analysis & 2 & Ambient temperature \\
\hline 5. & $\begin{array}{l}\text { Storage } \\
\text { condition }\end{array}$ & 1 & \\
\hline
\end{tabular}


Table 2: Different combination of refined wheat flour, butter and icing sugar

\begin{tabular}{|l|l|l|l|}
\hline Treatment & Refined wheat flour $[g]$ & Butter $[\mathbf{g}]$ & Icing sugar $[g]$ \\
\hline$T_{1}$ & 50.00 & 37.50 & 25.00 \\
\hline$T_{2}$ & 37.50 & 50.00 & 12.50 \\
\hline$T_{3}$ & 37.50 & 37.50 & 18.75 \\
\hline$T_{4}$ & 25.00 & 25.00 & 18.75 \\
\hline$T_{5}$ & 50.00 & 25.00 & 18.75 \\
\hline$T_{6}$ & 25.00 & 37.50 & 25.00 \\
\hline$T_{7}$ & 37.50 & 50.00 & 25.00 \\
\hline$T_{8}$ & 25.00 & 50.00 & 18.75 \\
\hline$T_{9}$ & 25.00 & 37.50 & 12.50 \\
\hline$T_{10}$ & 50.00 & 37.50 & 12.50 \\
\hline$T_{11}$ & 37.50 & 25.00 & 25.00 \\
\hline$T_{12}$ & 37.50 & 25.00 & 12.50 \\
\hline$T_{13}$ & 50.00 & 50.00 & 18.75 \\
\hline
\end{tabular}

\section{PREPARATION OF RED SPINACH POWDER \\ Cleaning}

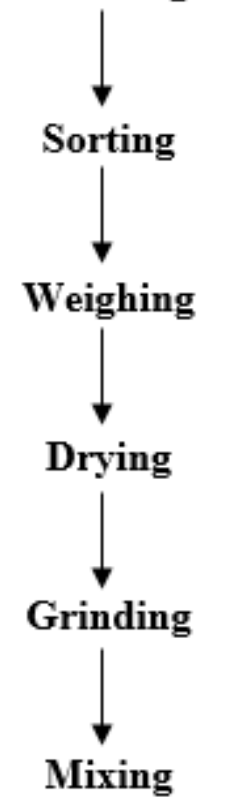

Figure 1: Flow chart for the preparation of red spinach powder

\section{Cleaning}

In this process unwanted impurities such as dirt, infectious agents were removed from the raw materials and it was also rinsed with tap water.

\section{Sorting}

The leaves were sorted on the basis of similar size and shape in order to acquire uniform drying of the raw materials. 


\section{Weighing}

The weights of the raw materials were taken according to the preparation of the product.

\section{Drying}

The raw materials were dried in the hot air oven [scientek] at a specific temperature for various hours.

\section{Grinding}

The dehydrated raw materials were grinded separately by using a mixer.

\section{Mixing}

The powdered raw materials were mixed in a proportion according to the requirement of the product.

\section{Methods}

The cookie was prepared with the raw materials of butter, refined wheat flour, baking powder, salt, icing sugar, Red spinach powder in different proportion. Cream the butter till it reaches the fluffy consistency. Add sugar to the butter and cream it well. Sieve the refined wheat flour, dehydrated and powdered red spinach powder three times into a plate and add salt and baking soda to it. Add refined wheat flour to the butter and mix it well. Sheet the dough and cut it according to the size of cookies. Transfer the dough into the greased tray and place it in the oven. Bake the cookies at $180 \mathrm{c}$ for 15 minutes.

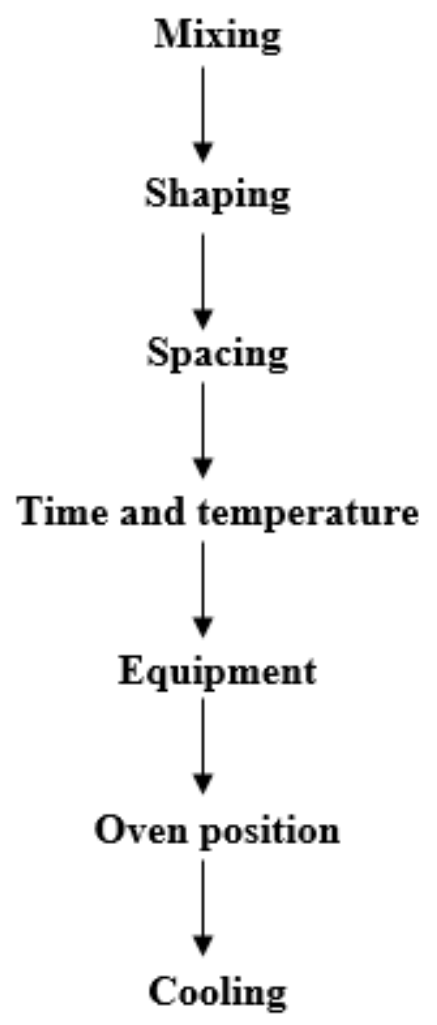

Figure 2: Flow chart for the preparation of cookies 


\section{Mixing}

Mixing develops gluten in the dough, giving cookies a chewy consistency. Beware of over mixing, which can turn chewy into tough, especially in dough that contains less than 50 percent fat by weight. Fat inhibits gluten development, so high-fat dough doesn't have the same toughening problem.

\section{Shaping}

Round dough balls take longer to bake, resulting in softer, thicker cookies. Flattening the balls yields thinner, crisper cookies.

\section{Spacing}

High-fat dough or cookies baked at low temperatures spread more during baking and need about 2 inches between them. High-flour cookies or those that bake for a shorter time need only an inch of space between them.

\section{Time and temperature}

These work together in baking. A low temperature and longer baking time yields crisper, thinner cookies; a higher temperature and shorter baking time makes softer, thicker cookies.

\section{Equipment}

Ovens can vary, so for accurate temperatures, check yours with a thermometer. For even heating, use heavy-gauge aluminum baking sheets, and line the pans with parchment to minimize hot spots, prevent sticking, and speed cleanup.

\section{Oven position}

For best results, bake a single sheet of cookies on the center rack. If baking more than one sheet, set racks in the upper and lower thirds of the oven and rotate sheets from top to bottom and back to front once during baking. This advice applies to convection baking as well.

\section{Cooling}

Cool cookies completely before storing, or trapped steam can turn them from crisp to soggy [7].

\section{Physico-Chemical Analysis of Red Spinach Powder}

\section{Moisture Content}

The accurately weighed red spinach powder was taken in a dry Petri dish. The Petri dish along with the sample was placed in the oven with the temperature at $105 \pm 1 \mathrm{C}$ for $2 \mathrm{hrs}$. The process is repeated along with drying, cooling and weighing for every 30 minutes. The moisture content percentage was calculated as:

Wet basis $[\% \mathrm{wb}]=\frac{\text { initial moisture content }- \text { final moisture content }}{\text { initial moisture content }} \times 100$

Dry basis $[\% \mathrm{db}]=\frac{\text { moisture content in decimals }[\text { in } \text { wet basis }]}{1-\text { moisture content }} \times 100$ 


\section{Ash Content}

The accurately weighed cookie was put into the dried crucible. The crucible was heated slightly on a flame and then heated in a muffle furnace at $550 \pm 10 \mathrm{C}$ for $3 \mathrm{hrs}$, until ash was formed.

The ash content percentage was calculated as;

Total Ash $[\%]=\left[\left[\mathrm{W}_{2}-\mathrm{W} 1\right] /\left[\mathrm{W}_{1}-\mathrm{W}\right]\right] \times 100$

Where;

$\mathrm{W}=$ Weight of empty dish

$\mathrm{W}_{1}=$ Weight of dish with powder

$\mathrm{W}_{2}=$ Weight of dish with ash

\section{Sensory analysis of developed cookies}

The sensory evaluation is used to measure the pleasurable and un-pleasurable experiences in food. This measure the overall quality of food. The samples were evaluated on the basis of color, taste, flavor, texture and overall acceptability by a panel of judges using 9-point hedonic scale.

\section{Results and Discussions}

\section{Physico-Chemical Analysis}

Moisture Content of Red Spinach Powder

\begin{tabular}{|l|l|l|l|l|l|l|}
\hline Time & Weight & $\begin{array}{l}\text { Moisture } \\
\text { Removed }\end{array}$ & $\begin{array}{l}\text { Moisture } \\
\text { Content[\%Wb] }\end{array}$ & $\begin{array}{l}\text { Moisture } \\
\text { Content[\%Db] }\end{array}$ & $\begin{array}{l}\text { Drying } \\
\text { Rate }\end{array}$ & $\begin{array}{l}\text { Moisture } \\
\text { Ratio }\end{array}$ \\
\hline 0 & 138 & 0 & 0 & 0 & 0 & 0 \\
\hline 1 & 66 & 72 & 52.173 & 109.090 & 4.32 & 0 \\
\hline 2 & 44 & 22 & 33.333 & 50 & 0.66 & 0.458 \\
\hline 3 & 29 & 15 & 34.090 & 51.724 & 0.3 & 1.034 \\
\hline 4 & 23 & 6 & 20.689 & 26.086 & 0.09 & 0.504 \\
\hline 5 & 20 & 3 & 13.043 & 15 & 0.036 & 0.575 \\
\hline 6 & 20 & 0 & 0 & 0 & 0 & 0 \\
\hline
\end{tabular}

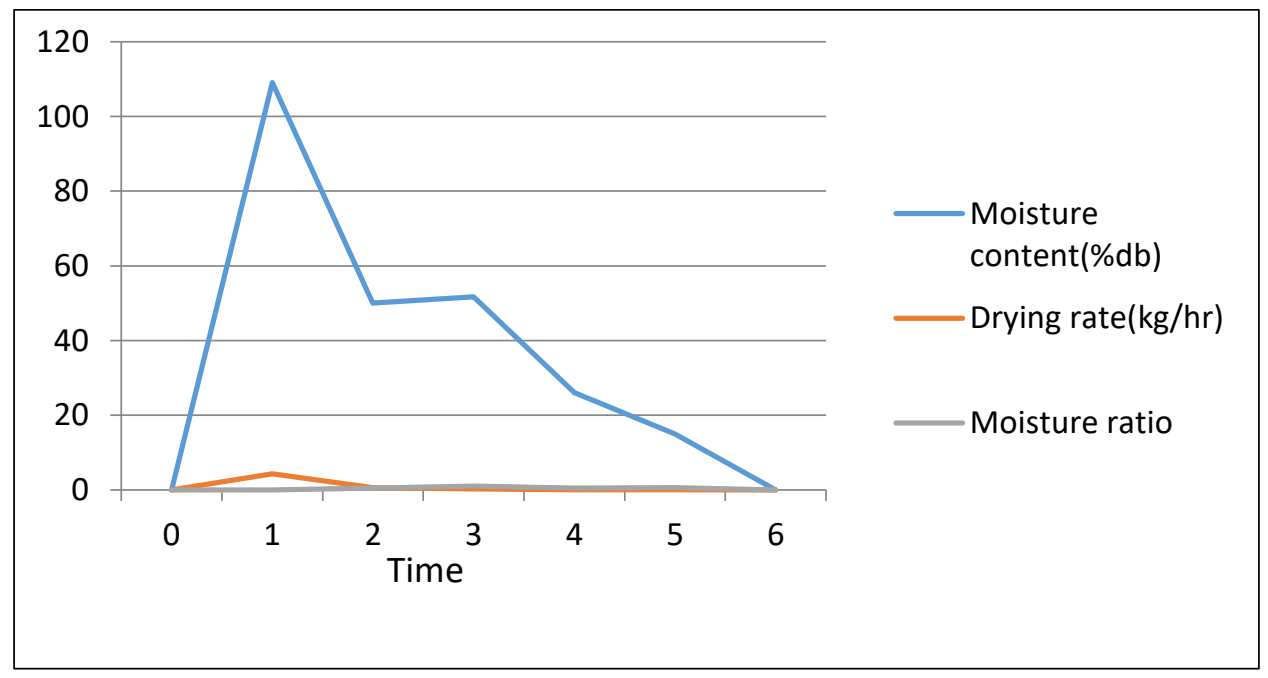




\section{Moisture Content of Cookies}

There was no significant difference was found in the percent of moisture content. The moisture content of the cookies differs with the change in concentration of the red spinach powder, this is attributed to high water binding capacity.

Ash Content of Red Spinach Powder

\begin{tabular}{|l|l|l|l|l|}
\hline S.No & Sample & Initial Weight & Final Weight & Ash Content \\
\hline 1 & Green leaf powder & 5 & 0.04 & $0.8 \%$ \\
\hline
\end{tabular}

\section{Ash Content of Cookies}

The ash content of the cookies increased significantly due to higher ash content of red spinach powder and due to added fat during the cookies preparation. The result of proximate composition of red spinach powder based cookies is similar with the other results.

\section{Sensory Evalution Analysis of Developed Cookies}

\begin{tabular}{|l|l|l|l|l|l|}
\hline Treatment & Colour & Taste & Flavour & Texture & OAA \\
\hline $\mathrm{T}_{1}$ & 7 & 7 & 6.75 & 6.45 & 7 \\
\hline $\mathrm{T}_{2}$ & 5 & 5 & 4.50 & 4.75 & 5 \\
\hline $\mathrm{T}_{3}$ & 9 & 9 & 9 & 9 & 9 \\
\hline $\mathrm{T}_{4}$ & 8 & 8 & 8 & 6 & 8 \\
\hline $\mathrm{T}_{5}$ & 3 & 3.5 & 4 & 4 & 4 \\
\hline $\mathrm{T}_{6}$ & 4 & 5 & 5 & 3 & 4 \\
\hline $\mathrm{T}_{7}$ & 5 & 4 & 4 & 3 & 4 \\
\hline $\mathrm{T}_{8}$ & 3 & 2 & 3 & 5 & 3 \\
\hline $\mathrm{T}_{9}$ & 5 & 6 & 4 & 6 & 5 \\
\hline $\mathrm{T}_{10}$ & 6 & 6 & 7 & 5.85 & 6 \\
\hline $\mathrm{T}_{11}$ & 3 & 4 & 4 & 5 & 4 \\
\hline $\mathrm{T}_{12}$ & 5 & 5 & 4 & 4.5 & 5 \\
\hline $\mathrm{T}_{13}$ & 8 & 8 & 7 & 8 & 8 \\
\hline
\end{tabular}

Cookies supplemented by different levels of substitutions of refined wheat flour, butter and icing sugar were sensory evaluated. Data indicated that the present score of biscuits containing refined wheat flour $[37.50 \mathrm{~g}]$, butter $[37.50 \mathrm{~g}]$ and icing sugar $[18.75 \mathrm{~g}]$ i.e., $\mathrm{T}_{3}$ was found to be the most acceptable. At this level of incorporation, all the attributes scored highest level. The incorporation of red spinach powder to the cookies to a level of $2 \mathrm{~g}$ does not affect the taste and flavour of the cookies.

\section{Conclusions and Recommendations}

It has been successfully demonstrated that dehydrated spinach powder could be safely employed as protein, mineral and fiber source in cookies. A reduction in fat content in the cookie can be highlighted with increased addition of spinach. The spinach incorporated cookies can be used as an alternative source to meet the fiber requirements. For treating anaemia, red spinach can be easily used solely because of the good levels of iron in them. To improve the kidney function and to clean the kidney, this spinach can be consumed along with the nodes for maximum results. This is also 
valid for women who has just given birth to a child and want to clean the organ well and regulate it [3].

\section{References}

[1] https://spinachwonders.blogspot.in/p/amaranthus-caudatusfox-tail.html?m=1

[2] ^a b c d e Nelson, Libby [29 November 2015]." British desserts, explained for Americans confused by the Great British Baking Show". Vox. Retrieved 2015-12-03.

[3] stylesatlife.com/articles/red-spinach-benefits/

[4] Antia [2006] Effect of texture modifiers on the physicochemical and sensory properties of dried fufu. Food sci. Technol Int 11:373-382

[5] ^van der sijs, Nicoline [sep 15,2009]. Cookies, coleslaw, and stoops: The influence of dutch on the North American Languages [paperback ed.].Amsterdam: Amsterdam university press.p.125.ASIN 9089641246.ISBN 978-9089641243

[6] ^Merriam-Webster's collegiate Dictionary, Tenth Edition .Merriam-Webster,inc.:1999.

[7] www.finecooking.com/article/the-science-of-baking-cookies-2

[8] Prabhakara Rao Pamidighantam, Nutritional, textural and sensory quality of biscuits supplemented with spinach [Spinacia oleracea L.], International Journal of Gastronomy and Food Science 7 [2017] 20-26.

[9] Srivastava et al., J Food Process Technol 2012, 3:12

\footnotetext{
*Corresponding author.

E-mail address: Dhanabaaghyamsweety@ gmail.com
} 